\title{
RUSYA'NIN KÜÇÜK HALKLARI VE KÜRESEL DÜNYADA HAYATTA KALMA SORUNLARI
}

\author{
THE PROBLEMS OF RUSSIA’S SMALL PEOPLES \\ AND THEIR SURVIVAL IN THE GLOBAL WORLD
}

\author{
Zaur ALIYEV ${ }^{i}$
}

\begin{abstract}
$\ddot{O} z$
Genel olarak makalede Rusyada yaşayan küçük halklar onların sosyo-kültürel, ekonomik, sosyal, demografik, iç politik sorunlarl, hayatta kalmalarl, onların ister Sovyet isterse de şimdiki devirde nasıl bir yaşam mücadelesi verdiği araştırılarak ortaya koyulmuştur. Genel olarak küçük halkların veya azınlıkların uluslararası koruma kanunlarının tam anlamıyla uygulanmadıkları belirlenerek gelecekteki bu gibi araştırmaların önünü açmaktadır.

Anahtar Kelimeler: Rusya, Azınlıklar, Küçük Yerli Halklar, Rusya'da Azınlıklar, Azınlıkların Sorunlart.
\end{abstract}

\begin{abstract}
Generally, the small peoples living in Russia have been exposed to their socio-cultural, economic, social, demographic, domestic political problems, survival, and how they survived in the Soviet or the present period. In general, it is determined that international protection laws of small peoples or minorities are not fully implemented and paves the way for such research in the future.
\end{abstract}

Keywords: Russia, Indigenous Peoples, Minorities, Minorities in Russia, Problems of Minorities.

\section{GİRIŞ}

Dünya üzerinde yaşayan halk ve dil sayısını söylemek güçtür. Çünkü birçok yerlerdeki farklı konuşmalar dil midir değil midir henüz yapılan bir tanımlama yoktur. Fakat yaklaşık 35004000 adet dil olduğu sanılmaktadır. Halk olarak da yaklaşık 2000-2500 halk olduğu sanılmaktadır. Halklarda da dil ve etnik unsurlar tam belirlenemediği ve birbirlerine karıştıkları için kesin sayı vermek mümkün değildir.

Küçük azınlık halklar genelde büyük devletlerin içerisinde parça halinde veya bütün olarak yaşamaktadır. Ama sorun onların yaşamlarında değil, nasıl yaşadıklarında ve ne gibi sorunlarla yüzleştiklerindedir. $\mathrm{Bu}$ gibi büyük devletlerde yaşayan azınlıkların hakları aliyev78@gmail.com, ORCID: 0000-0002-6219-8062. 
korunuyor mu? Onların bugünkü durumu ne? Uluslararası Azınlık koruma kanunları çalışıyor mu? Sorularına cevap bulmak için çok sayıda küçük azınlıkların yaşadığı genel olarak Sovyet döneminden şimdiki Rusya'da bir araştırma yaparak bu makaleyi verilere dayalı olarak oluşturduk.

Rusya inanılmaz çeşitlilik gösteren bir ülkedir. Rusya'nın büyük bir etnik, kültürel, dini ve dilsel çeşitliliği var. Resmi politikası ve mevzuatı, ülkenin çok uluslu nüfusunun sorunlarını kabul etmekte ve kısmen düzenlemektedir.1993 Rus Anayasasının 19. Maddesinin 2. Bölümü eşitliği garanti eder (Rusya Federasyonu Anayasası, 2009):

"Herkes yasa ve mahkeme önünde eşittir”.

"Devlet, cinsiyet, ırk, milliyet, dil, köken, mülk ve resmi statü, ikamet yeri, dine karşı tutumu, inanç, kamu kuruluşlarına üyelik gibi ve diğer koşullara bakılmaksızın, her bir kişinin ve vatandaşın hak ve özgürlüklerinin eşitliğini garanti eder. Vatandaş haklarının sosyal, ırksal, ulusal, dilsel veya dinsel bağlılık temelinde herhangi bir şekilde kısıtlanması yasaktır.”

\section{KÜÇÜK YERLİ HALKLAR KAVRAMI (KYH)}

Rusya Federasyonu mevzuatına göre, Küçük Yerli Halklar (KYH) neseplerinin tarihi yerleşim bölgelerinde ikamet eden ve yaşam tarzlarını, geleneklerini, ticaretini ve ekonomisini koruyarak yaşayan nüfusun özel gruplarına denir. Rusya İmparatorluğu’nda, küçük ulusların haklarının korunmasını amaçlayan ilk yasal işlemlerden biri, 1822'de kabul edilen "YABANCILARIN YÖNETIMM SÖZLEŞMESI'” (Rusya İmparatorluğunun Sibirya yerli halkları için bir yönetim, özyönetim ve mahkeme sistemini içeren yasama yasası) olmuştur. 1920’lerde Merkezi Yürütme Komitesi ve 10/25/1926 tarihli Halk Komiserlerinin kararnamesiyle XX. yüzyılda "Kuzey nahiyelerinin yerli halklarının ve kabilelerinin yönetimine ilişkin Geçici Kanunun onaylanması üzerine” başlangıçta kapalı bir liste kuruldu. 24 etnik topluluk içeren "Yerli Halklar” terimi ilk olarak 1993 yılında Rusya Federasyonu Anayasasına getirildi. Rusya’da 40 Kuzey, Sibirya ve Uzak Doğu halkı (bunlardan en önemlileri Aleutlar, Ketler, Mansiler, Nanaylar, Nenetsler, Saamiler, Udegeyler, Hantiler, Çukçiler, Şorlar, Evenkler, Evensler, Eskimolar ve Yukagirler), o cümleden Abazin, Besermyan, Vod, Ijor, Nagaybak, Şapsug ve 14 Dağıstan halkı dâhil olmak üzere Tek Bir Yerli Azınlıklar Listesi'ne aittir. 2006'da bu listeden ayrıca “Rusya Federasyonu'nun Kuzey, Sibirya ve Uzak Doğu Yerli Azınlıkları Listesi” seçildi. Rusya yasalarına göre, bir KYH halkının tanınması için aşağıdaki koşullar yerine getirilmelidir:

- Topluluk kendisini tanımlamalı (yani kendisini bağımsız bir etnik topluluk olarak tanir);

- Topluluk tarihi yerleşim bölgesini ve geleneksel el sanatlarını, kendine özgü kültürü, ortak ana dilini korumalı;

- Topluluğun yaşadığı bölgelerde kendine has bir ekonomik alan mevcut olmalı.

- Sözügeçen topluluğun Rusya'da ikamet eden temsilcilerinin sayısı 50 binden az olmal1.

Yerli halkların hepsinin küçük sayılarda olmadığı da unutulmamalıdır. Örneğin, Rusya yerli halklarından, Rusya topraklarında yaşayan ve sayıları 300 binin üzerinde olan Komi ve Yakut halkları var. Rusya’nın etnik azınlık haklarının statüsü ve korunmasına ilişkin yasama 
hükümleri, uluslararası normlara ve Rusya'nın insan hakları konusunda uluslararası anlaşmalarına ve ulusal azınlıkların haklarının korunmasına dayanmaktadır. KYH, devlet tarafından özel korumanın sağlanması amacıyla ayrıca bir halk grubuna tahsis edilmiştir. Halk temsilcilerine özel bir statü verilmektedir, bazı yasal menfaatler de sağlanmaktadır (biyolojik kaynakların tercihli kullanımı, düşük emeklilik yaşı, alternatif askerlik hizmetinin yerine getirilmesi (örneğin geyik otlatma), arazi vergisinden muafiyet vb.). Bu durumda, Rusya Federasyonu'nun birimleri kendi bölgelerinde yaşayan küçük halkların sorunlarını bağımsız olarak çözmektedir.

\section{YENIDEN YERLEŞIMIIN ÖZELLIKLERİ VE RUSYA'DA YERLİ HALKLARIN FAALIYETLERI}

Nadir istisnalar dışında Rusya'nın tüm KYH'lari, bölge ilkesine göre iki gruba ayrılabilir:

- Kuzey KYH’lar (alt grupları: Sibirya ve Uzak Doğu'nun KYH’ları ve Avrupa Kuzeyinin KYH'larını içeriyor)

- Kuzey Kafkasya'nın KYH'ları. Kuzey "Sibirya” yerli halkları ve Uzak Doğu farklı kategorilerdedir. Rus mevzuatı bunları "az" olarak sınıflandırmaktadır, çünkü bu tür gruplara ait kişi sayısı 50.000’i geçmemektedir. Rusya federal mevzuatı Rusyadaki küçük halkların topraklarının ve geleneksel yaşam biçiminin korunmasında için özel haklar sağlamaktadır.

Geleneksel ikamet yerlerinin listesi ve kuzeydeki KYH'ların geleneksel ekonomik faaliyetlerinin türleri, Rusya Federasyonu Hükümeti tarafından onaylanmaktadır. Göçebe ren geyiği çobanları, mevsimlik avcı, toplayıcı ve balıkçıların rotaları, kutsal yerler, dinlenme yerleri vb. kültürel olarak gelişmiş bu bölgelerin kapsamı son derece geniştir: Taymır Yarımadası'ndaki Dolgan ve Nganasalılardan, Habarovsk Krayı'ndeki Udegey halkına, Komandor Adalarındaki Aleut'lardan Murmansk bölgesindeki Saami’lere kadar.

Devlet listesine göre küçük halkların geleneksel iktisadi faaliyet türleri:

- Hayvancılık, dâhil göçebe (ren geyiği, at, yak, koyun yetiştiriciliği);

- Derilerin, yünlerin, saçların, kemiksiz boynuzların, toynakların, geyik boynuzlarının, kemiklerin, endokrin bezlerinin, etin, sakatatlarının toplanması, satın alınması ve imalatı dâhil hayvansal ürünlerin işlenmesi;

- Köpek yetiştiriciliği (ren geyiği sürülmesi, binicilik ve av için köpekler);

- Kürk ürünlerinin işlenmesi ve pazarlanmasi;

- Arıcilik;

- Balıkçılık ve sudaki biyolojik kaynakların satışı;

- Deniz hayvanları avcılığg

- Ticari avcılık, avcılık ürünlerinin işlenmesi ve satışı. Tarım (bahçecilik) yanı sıra şifalı bitkilerin yetiştirilmesi ve işlenmesi;

- Ağaç ve kereste dışı orman kaynaklarının kendi ihtiyaçları için toplanması;

- Toplama;

- Ortak minerallerin kendi ihtiyaçları için çıkarılması ve işlenmesi;

- Sanat ve el sanatları

- Geleneksel ekonomik faaliyetlerin uygulanması için gerekli olan ulusal geleneksel konutların ve diğer binaların inşası. 


\section{KÜRESELLEŞME SÜRECI VE HALKLARIN SOSYO-KÜLTÜREL SORUNLARI}

Yerli okuryazarlık ve eğitim durumu ülkenin geri kalanından daha düşüktür (UN Human Rights Council - UNHRC, 2007). Yerli halklar genellikle dağınık ve uzak bölgelerde yaşarlar; bu yüzden çocukları genellikle yatılı okullara (internat-okulu) gittiğinden düşük bir eğitim seviyesine sahip oluyorlar. Ayrıca, federal düzenlemeler yerel topluluklar için fazla katkıda bulunmuyor: bunun için yeni programlar belirlenerek öğretmenler ayarlanmaktadır (sınırlı ölçüde) (UN Human Rights Council - UNHRC, 2010). Bu da birkaç dilin öğrenilmesi için zorluklar oluşturmaktadır. Bazı eğitim materyalleri sağlanmış olmasına rağmen, kaynakları çok kısıtlıdır. Toplulukların yaşadığı yerlerin uzaklığından kaynaklı bu dillerin öğretilmesinde zorluklar yaşanmaktadır (UNESCO, 2014).

Yerli azınlıklar, kültürlerinin modern medeniyetin gereksinimlerine uyum sağlama konusundaki son derece sınırlı kabiliyetlerinden dolayı, doğal olarak özel bir grupta öne çıkıyor. Bu halkların arasında en büyük şoku yaşayanlar da KYH'lardır. Bu tür halkların aşırı yaşam koşullarında ikamet etmesi, bu şartlara uyum sistemine ve kendine has belirli kültürlerin yaratılmasına yol açtı. Bu nedenle, küçük ulusların yaşam tarzı etkili bir piyasa ekonomisinin gereksinimlerine uyarlanamaz. Bu yüzden, Kuzey’in küçük halklarına yönelik politikası zor bir soruyla karşı karşıya kalmaktadır: Küçük halkların yaşam tarzlarını geleneksel biçimlerinde korumak mı yoksa KYH'ların modern egemen kültür sistemine dâhil edilmesini teşvik etmek mi?

Sovyetler Birliği zamanında, kuzeydeki küçük etnik gruplar ekonomi gelişimi, geçtiğimiz yüzyılın 30'larında yapılan kollektifleşme ve ikinci yarısında başlayan doğal kaynakların endüstriyel gelişimi gibi ciddi olaylardan etkilendi. 90’lı yıllarda pazar ekonomisine geçiş de etki açısından büyük önem taşımış oldu.

Kuzey yerli halklarının temsilcilerinin neredeyse \%50'si orta öğretim ve dahası yüksek eğitimi yoktur. Bunlardan \% 17'si tamamen okuma yazma bilmemektedir. Ortalama yaşam süresi 49 yıldır (Bilgi ve analitik portalı “Naslediye”, 2000). Farklı uluslar farklı yaşam tarzlarıyla karakterize ediliyor: göçebe, yarı göçebe, hareketsiz.

\section{YAKUTISTAN'DA İKAMET EDEN HALKLAR}

\section{Evenkler}

Doğu Sibirya'nın yerli halkıdır. Ayrıca Moğolistan ve Çin'in kuzeydoğusunda da yaşıyorlar. Evenki dili Altay dil ailesinin Tungus-Mançurya grubuna aittir. Üç lehçe grubu vardır: kuzey, güney ve doğu. Her lehçe ağızlara bölünmüştür (Russian Association of Indigenous Peoples of the North - RAIPON, 2003).

Evenkler toplamda 30 binden az insanın olduğu eski zamanlardan beri, Sibirya'nın geniş alanlarında yaşıyor. Bu eşsiz insanlar binlerce yıldır sert Rus topraklarını benimseyip Çin ve Moğolistan'a kadar ulaşmışla. Bugüne kadar nesepleri olan Tungus'ların kültürünü ve dilini korumayı başardılar. Yaşam tarzlarının pek çok özelliği tüm kuzey halklarının kültürüne benzemektedir, ancak aynı zamanda belirli ulusal özellikleri de vardır. Evenkler, Rus Sibirya'sının en eski yerli halklarından biridir. Bu milletin kökenine dair birkaç teori var. Birincisine göre, Paleolitik çağdan gelişen Evenk kültürünün orijinal vatanı Baykal gölünün 
güney bölgeleri kabul edilir. Ancak çoğu araştırmacı, Evenklerin Doğu Sibirya Aborjinlerinin, Baykal ve Transbaykalya'da dolaşan Tungus kabileleriyle birleşerek oluşturulduğuna inanıyor (Russian Association of Indigenous Peoples of the North RAIPON, 2003).

Bu teori, Evenklerin ortaya çıkışını Sibirya'da yerleşik olan ve yerel kabileleri asimile eden bir grup “uvan” yetiştiriciyle ilişkilendirir. Çağımızın 1-2 bin yılında kuzeye doğru hareket eden Yakutlar, Evenkleri doğu ve batı Evenklere ayırdı. Bu, öncelikle ren geyiği sürü türünü etkileyen bazı kültürel farklılıklar yarattı.

Yüzyıllar boyunca, Evenkler farklı liderleri olan kabileler halinde yaşadı. Yaşamları, göçebe bir yaşam tarzına maruz kaldı. Evenkler, geyik karavanlarının yardımıyla geçici park yeri organize ederek hareket ediyordu. Yerleşik geleneklerin olmamasına rağmen, Evenkler, kendileri için Sibirya beyzadeleri ismini kazandıran zengin bir kültür oluşturdu.

Evenkler, insan ve doğa arasında uyumlu bir düet yapmış olan, bugüne kadar hayatta kalan birkaç ulustan birini temsil ediyor. Binlerce yıllık varoluşunun zamanı, Tungus göçebe medeniyeti, tek bir hayvanat ve bitki türünü tahrip etmemiştir. Doğaya saygı, Evenk hayatının felsefesiydi. Taşların, akarsuların, kayaların ve ağaçların ruhlarına inananarak doğayı insan gibi canlı olarak görüyorlardı. Tapınma kültüyle ilgili kurallar ve kısıtlamaları vardı: ağaçları gereğinden fazla kesmemek, avını gereksiz yere öldürmemek, geçici avlanma kamplarının bölgelerini temizlemek gibi.

Hayvanlar arasında, Evenkler özellikle fikirlerine göre Tayga'nın sahibi ayıya saygı duyuyordu. Bu inanca göre, avcılara sınırlı sayıda hayvanı öldürme izni verilir ve izin verilen sayıyı aşma durumunda ihlalciye maliyeti hayatı pahasına olabilirdi.

Etnografik araştırmalara göre, Evenkler eski zamanlarda hava mezarı törenini uygulardı cesedin havaya, ruha ve 1şığa verilmesi için ölen kişinin vücudu havada asılıyordu. Kafkas halkları arasında da antik çağda bu törenin yaygın olduğu dikkat çekiyor.

\section{Evenler}

Evenklerle yakın olan ancak Yakutistan Cumhuriyeti'nin doğu kesiminde ve Çukotka Özerk Bölgesi’nde bulunan bir ulustur. Evenler, aktif misyonerlik faaliyetinin vesilesi ile Kuzey’in en çok Hıristiyanlaştırılmış halklarından biridir. Evenlerin yerleşim yerlerinde Ortodoks kiliseleri ve şapeller inşa edilmiştir. XIX. yüzyılın 50’li yıllarında. Başpiskopos S. Popov dua metinlerini, İncil'i ve "Tungus Alfabe” sini kilise bazında yayınladı. Rahip A. I. Argentov, Kolıma'da hele XIX. yüzyılın başında “putperestlerin” ortadan çekildiğini belirtti. Hristiyanlık, Even yaşamının neredeyse tüm yönlerini kapsıyordu. Doğum, evlilik, ölüm, iç davranış, tören ve bayram adetleri, her şey Ortodoks geleneği tarafindan düzenlenmiştir (Polyanin, 2012).

Evenler in dini temsillerinde, doğanın "sahipleri” ve unsurlarına inanç yer alıyordu: tayga, ateş, su, vs. Kendisine geyikler kurban edilen güneşe ibadetin özel bir yeri vardı. Kaynak putlarına, doğa sahibi ruhlara inanç, şamanizm gelişmişti. XVIII - XIX. yüzyıllara kadar Evenler arasında ağaçlarda veya kazık platformlarına uygulanan hava mezarları yaygındı. Ortodoksluğu kabul ettikten sonra, Evenler, ölüleri toprağa gömerek mezarın üstüne haç koymaya başladı. XVII - XVIII. yüzyıllarda Evenler, ölü adamı mevsime göre en iyi kıyafetlere giydirerek, ağaçların üzerine ya da sütunların üstünde bina edilen tahta bir güverteye koyardı. Birkaç geyik keserek kanı tabutun ve ağaçların üzerine atılırdı. Ölen 
kişinin kancasını, eşyalarını, vb. ise ağaçların altında burakılırdı. I. A. Hudyakov (1842-1876 Halkbilimci, Etnograf, Araştırmacı-Yazar), İndigir Lamut’ları (Evenler) ölünün “doğuya gideceğine” inandıkları için ölüleri kafalarını batıya taraf koyarak gömdüklerini yazıyordu (Polyanin, 2012).

Halkbiliminde masallara ve hikaye efsanelerine büyük önem veriliyordu. Masalların arasında, Evenklerin masallarına benzer şekilde hayvanların ve kuşların masalları göze çarpıyor. İlgili efsanelerin bazı bölümleri, örneğin kahramanların konuşmaları genellikle şarkıyla söylenirdi. Destanlar arasında erkekleri yenen kadın kahramanlarla ilgili destanlar özellikle ilginçtir.

Genel olarak destansı bir karakterin eserlerinin performansı zamanı destanların şarkı aktarımının yaygın olarak kullanıldığı ve neredeyse her karakter için kendine has bir melodi kullanıldığı belirtilmelidir.

Evenlerdeki düğün törenleri temel olarak Evenklerinkine benzer. Gelin için “tori” - başlık parası ödenirdi. Onun değeri çeyizin iki ya da üç misline eşitti. Başlık parasını ödedikten sonra gelinin ebeveynleri ve diğer akrabaları, gelini çeyizi ile birlikte damadın ebeveynlerine getiriyorlardı. Gelin, üç kez evin etrafını güneşin altında dolaştıktan sonra ailesi onu damada teslim ediyordu. $\mathrm{Bu}$ törenin ardından gelin, gençlere yeni bir gölgelik yerleştirilmiş olan çadırın içine giriyordu. Kazanını çıkarıp avlanmış bir geyiğin etini pişirmeye başlardı. Çeyiz, evin dışarısında sergi amaçlı asılıyordu.

Bir bebeğin doğumunda, sürüde kendisine belirli sayıda geyik tahsis ediliyordu. Kız çocuğu büyüyüp evlendiğinde ise bu geyiklerin üremesinden oluşan bir sürü çeyiz olarak kendisine verilirdi.

\section{6. ÇOĞUNLUKLA ÇUKOTKA ÖZERK BÖLGESİ'NDE YAŞAYAN HALKLAR}

\section{Yukagirler}

Rusya Federasyonu'ndaki, Doğu Sibirya'da, Yakutistan'da (bin kişi) yaşayan halktır. Tundra Yukagirleri Aşağı Kolıma'da, Tayga Yukagirleri ise Yukarı Kolıma'da yaşar. Rusya Federasyonu'ndaki toplam nüfusu bin beşyüz kişidir. Genellikle Ortodoks Hıristiyanlardır. Antropolojik olarak, Yukagirler Kuzey Asya 1rkının Baykal tipine aittir, ancak bir takım unsurlara göre Ural grubunun halklarına yakındır (Mansi, Nenets, Hantı). Yukagir dilinin sistematik konumu belirsizdir: genel olarak Paleo-Asya dilleri grubuna (ailesine) dahil ediliyor, ancak bazı bilim adamları Yukagir dilini yalıtılmış bir dil olarak görür

17. yüzyılda, Rus kolonizasyonunun başlangıcında, Yukagir kabile grupları, Lena Nehri’nden Anadır Nehri’nin ağzına kadar olan arazilerde yaşıyorlardı. Düşük bir etnik kimliğe sahiplerdi. 17. ve 19. yüzyıllarda epidemi, iç çatışmalar, saldırılar nedeniyle Yukagirlerin sayısı azaldı; bazı Yukagirler Yakutlar, Evenler ve Ruslar tarafindan asimile edildi. 1897'de 754 1970'de yaklaşık 600 Yukagir vardı. Daha sonra Yukagirlerin sayısı artmaya başladı. Yukagirlerin toplumsal ilişkileri uzun süre anayersel evliliğin kalıntılarını korudu. 19. yüzyıldaki Hıristiyanlaşmaya rağmen, kabile şamanları Yukagirler arasında büyük bir etkiye sahipti.

19. yüzyılın sonunda, etnik gelenekler esasen Kolıma Yukagirleri tarafindan korunmuştu. Ekonomilerinin temelinde tundra Yukagirleri için vahşi geyik avlamak ve taşıt olarak kullanılan ren geyikçiliği yer almışken, Yukarı Kolıma Yukagirleri ise toynaklı hayvan 
avcılığı, balıkçılık, köpek yetiştiriciliği ile meşgul olmuşlardı. 18. ve 19. yüzyıllar boyunca Yukagirlerin maddi kültür unsurları Even, Çukça ve Yakut’ların (araçlar, ulaşım, giyim) etkisine maruz kalarak oluşuyordu. Aynı zamanda, vahşi geyik avcılarının eski çevresel kültürüne dayanan bir takım arkaik özellikler (nesepler ve şaman inancı, köpeklerin kurban edilmesi, "karga” destanı), Yukagirlerin kültüründe korunmuştur.

Yukagir Dili Ile Ilgili Mevcut Duruma baktığımızda; 2011’de, Magadan bölgesindeki Srednekanski bölgesinin Yukagirlerine aşağıdakileri gözlemlerle sonuçlanmış bir sefer yapıldı (Prokopyeva, Shadrin\&Prokopyeva, 2012):

- Bazı erkekler boş zamanlarında avlandıklarını veya balık avladıklarını söylese de, geleneksel sektörlerde uğraşan tek bir Yukagir tanımlamak mümkün olmadı;

- Ankete katılan Yukagirlerin çoğu, halklarının ayinleri ve gelenekleri hakkında hiçbir fikre sahip değildir ve kendi yerel folklorları hakkında bilgi sahibi değildir;

- Srednekanski bölgesinde araştırılan Yukagirler arasında, nesebinin üçüncü neslinin yalnızca Yukagirlerden oluşan kimse yoktu;

- Mülakat yapılan yaşlı Yukagirler yerel masallarını hatırlamıyorlardı, ama masal karakterlerinin adlarını biliyorlardı;

- Yukagir dili, nesli tükenmek üzeredir, 69 Yukagirden sadece 6'sı bu dile hakim.

\section{Çukçiler}

Bering Denizi'nden İndigirka Nehri'ne ve Arktik Okyanusu'ndan Anadır ve Anyuy Nehirlerine kadar geniş bir alana dağılmış, Asya'nın uzak kuzey doğusundaki küçük bir yerli halktır. 2010 Tüm Rusya sayımlarına göre nüfusu - 15.908 kişiden ibarettir. 2010 nüfus sayımına göre, Çukçilerin mutlak çoğunluğuna sahip olduğu tek il Çukotka Özerk Bölgesi'ndeki Çukotka ilidir (\% 70) (Russian Association of Indigenous Peoples of the North - RAIPON, 2003).

Daha İlkçağda Ruslar, Yakutlar ve Evenler, çobanları Çukça olarak adlandırıyordu. "Çukça" ismi "chauchu” kelimesinden gelerek - "geyiklerle zengin" anlamını taşımaktadır. Geyikler ile meşgul kişiler kendilerini böyle isimlendiriyor. Köpek yetiştiricileri ise "ankalini" olarak adlandırılıyor. Bu halk, Asya ve Amerikan türünün karışmasının sonucunda oluştu. Bu, Çukçi köpek yetiştiricileri ve Çukçi ren geyiği yetiştiricilerinin yaşama ve kültüre karşı farklı tutumlara sahip olması, çeşitli efsaneler ve mitlerin bundan bahsettiği gerçeği ile doğrulanmaktadır (Russian Association of Indigenous Peoples of the North - RAIPON, 2003).

Çukçi dilinin dilsel ilişkisi henüz kesin olarak belirlenmemiştir, bu dil köklerinin Koryakların ve İtelmenlerin dillerine ve eski Asya dillerine gittiğini gösteren varsayımlar vardır (Bogoraz, 1934). Çukçiler, geyik yemi biter bitmez kaldırılan ve yeni bir yerde güncellenen kamplarda yaşam tarzına alışıktır. Yaz aylarında denize daha yakın inerler. Sürekli yer değiştirmeleri yeterince büyük konutlar inşa etmelerini engellemez. Çukçiler, geyik derileri ile kaplı geniş bir poligonal çadır inşa eder. Bu yapının kuvvetli rüzgara dayanabilmesi için adamlar tüm barakayı taşlarla destekliyor. $\mathrm{Bu}$ çadırın arka duvarında insanların yemek yedikleri, dinlendikleri ve uyudukları küçük bir yapı var. Kendi odalarında fazla terlememek için yatmadan önce neredeyse çıplak soyunurlar. 
Çukçilerin yerel kıyafetleri rahat ve sıcak elbiselerden ibarettir. Erkekler çift kürklü gömlekler, çift kürklü pantolon, ayrıca kürklü çoraplar ve aynı malzemeden yapılmış botlar giyerler. Erkek şapkası biraz kadın başıı̆ını hatırlatır. Kadın kıyafetleri de iki katmandan oluşuyor, sadece pantolon ve üst kısım birlikte dikilir. Yaz aylarında, Çukçiler daha hafif giysiler - süet geyiklerinden ve diğer parlak kumaşlardan yapılmış tulumlara geçer. $\mathrm{Bu}$ kıyafetlerde adeta güzel ritüel nakışları bulunur. Bebek ve küçük çocuklar kol ve bacaklar için kesikleri olan ren geyiği derisinden yapılmış torbalara konur.

Çukçi'nin ana ve günlük yiyeceği hem hazır hem de çiğ halde yenen ettir. Beyin, böbrek, karaciğer, gözler ve kirişler çiğ şekilde yenebiliyor. Ağaç köklerini, gövdelerini ve yapraklarını yiyen ailelere de sık rastgelebilirsiniz. Çukçi halkının alkol ve tütün sevgisini de kaydetmeye değer.

Çukçiler - ata geleneklerini koruyan bir halktır. Bu bakımdan da onlar hangi gruba ait olursa olsun - çobanlar veya köpek yetiştiricileri - önemli değildir. Çukçilerin ulusal bayramlarından biri Baydarı (kayık, tekne) bayramıdır. Çukçiler eski zamanlardan beri et bulmak için tekne kullanıyorlar. Ve her gelecek yılda suların Çukçi teknelerini "kabul etmesi” için halk belli ayinler düzenlerdi. Tekneler, tüm kışı balina çene kemiğinde bekletildikten sonra çıkarılıyordu. Ardından denize gidilerek ona (denize) haşlanmış et şeklinde kurban verilirdi. Bundan sonra, "baydar" (tekne) evin yanına koyularak etrafına bütün aile ile dolaşıllyordu. Ertesi gün aynı ayin tekrarlanıyor ve yalnız bundan sonra tekne suya indiriliyordu. Bir diğer Çukçi bayramı da balina bayramıdır. Bu bayram, öldürülen deniz hayvanlarından özür dilemek ve deniz sakinlerinin sahibi olan Keretkun'un karşısında olan günahlarını hafifletmek için yapılıyordu. İnsanlar mors bağırsaklarından su geçirmez ve zarif kıyafetlerini giyerek morslar, balinalar ve foklar önünde özür dilerdiler. Onları öldüren avcılar değil, kayalardan düşen taşların olduğu hakkında şarkılar söylerdiler. Bundan sonra, Çukçiler denizlerin efendisine kurban olarak denizin derinliklerine balina iskeletini indiryordu. İnsanlar bu şekilde öldürdükleri bütün hayvanları dirilteceklerine inanıyorlardı.

Tabii ki Kilvey adlanan bir başka geyik bayramına da deyinmemek yanlışlık olurdu. $\mathrm{Bu}$ bayram ilkbaharda kutlanıyordu. Her şey, geyiklerin insan meskenlerine, “yarang”lara getirilmesi ve kadınların ateş yakmasıyla başlıyordu. Yalnız ateş yüzyıllar önce olduğu gibi sürtünme yolu ile yakılmalıydı. Çukçiler, geyiklerinden kötü ruhları uzaklaştırmak için onları coşkulu sesler, şarkılar ve ateş sesleriyle karşılardı. Kutlama sırasında ise erkekler, çocuk, kadın ve yaşlıların gıda stoklarını yenilemek için birkaç yetişkin geyiği kesiyorlardı (Obsheobrazovatelnıy Jurnal "Sezonı Goda", 2011).

\section{UDEGEYLER: UDEGE DİLI. ŞUANKİ DURUMU}

Udegeyler Uzak Doğu'da yaşayan KYH'dan biridir. Antropolojik olarak halk, Baykal tipi Moğolitlere aittir. 20. yüzyılın başındaki duruma göre, Udege halkı sürekli olarak SikhoteAlin'in her iki yamacında olan arazileri kapsıyordu. Toprakları doğuda Japonya Denizi kıyılarına, batıda ise Ussuri nehrinin sağ kollarına (Hor, Bikin, Bolshaya Ussurka nehirleri) ulaşıyordu. Udegey halkının yaşam sınırları kuzeydoğuda İmparatorluk limanının Oroçları, kuzeyde Naiha Nanayları, güneyde ise Tazların sınırlarına dayanıyordu. Buna ek olarak, Udegeyler ana bölgelerinden kuzey ve kuzeybatıda yerleşen Amur nehrinin kolları boyu (Anuyu, Hungari ve Urmi), Nayha ve Kururmi Nanaylarin bölgelerinde de ikamet ediyorlardı. 
Bununla birlikte, 1930’larda tüm Kuzey Rus halklarının zarar gördüğü yerleşimlerin kollektifleşmesi ve genişlemesiyle bağlı olarak Udegey halkı da asimilasyona uğradı. Sonuç olarak, 1940'ların başında, Udegey halkı etnik torpak birliğini tamamen kaybederek 9 genişletilmiş köyde yoğunlaştı. Bu köyler "Ruslarınkinden farklı olmayıp” günümüzde Rusya Federasyonun Primorski ve Habarovsk Kraylarında (bölgelerinde) bulunuyor.

Udegeyler, Altay ailesinin Tungus-Mançurya dil grubunun güneyindeki (Amur) alt grubuna ait olan Udegey dilinde konuşuyor. Udegey dilinin en büyük yakınlığı Oroç dili ile olduğu gözlenmektedir (Kormushin, 1998). Şu anda, Udegey dili kendi yerini neredeyse tamamen Rus diline vermektedir.

Udegey dilinde konuşanların sayısı sürekli olarak azalmakta - örneğin, 2010 nüfus sayımında, Udegey dilini kendi ana dili olarak bildiren yalnızca 82 Udegeyli (\% 5.64) olmuştur; diğerleriyse ana dili olarak Rus dilini belirtmiştir (Kulturologiya, 2008).

2002'de Udegey uyruklu olduğunu belirten 1.657 kişi vardı, ancak Udegey kökenli birçok insan şehirlerde veya şehir tipi yerleşimlerde yaşayarak Ruslarla asimile edilmişti ve böylece anadilinde konuşanların sayısı keskin bir şekilde düşmüş oldu. 2002'de yalnızca 400 civarında insan Udegey dilini ana dili olarak tanımladı ve bunlardan çoğu yaşlı neslin temsilcileri olmuştur.

Udegey halkının ikamet yerlerinde mevcut olan ana sorunlarından biri sakinleri arasında çok yaygın olan alkolizmdir. Diğer bir problem ise, 1990’larda sık sık çatışmalara yol açan büyük şirketlerin topraklarında yaptığı ağaç kesme çalışmalarıdır.

\section{Udegey Kültürü}

Udegeylerin sosyal gelenekleri epeyce arkaik özelliklerle doludur - örneğin, 19. yüzyılın ortalarına kadar, Udegey toplumu aşiret ilişkilerinin egemenliği altındaydı. Aşiretin her bir üyesi, geleneksel yasalarla birlikte, yalnızca kendi yetkinliğini (aile ve meslek-endüstri ilişkilerini) değil, aynı zamanda kişisel özgürlüğü de daha kesin olarak belirleyen, kontrol eden ve sınırlayan kabile üyeliğini biliyordu.

Aşiret başında, aşiretın en yaşlı ve en yetkili adamlarından seçilen bir yaşlı (Sagdimzi; veya Zangia - "prens”) dururdu. O otorite ile yetkilendirilen kişiydi, ayrıca "yasa"nın (çevrenin), yani geleneksel yasaların korunmasını kontrölünü yaparak, ihlali durumunda mahkemeye önderlik ediyordu. Aşiretler arası bir çatışma durumunda (örneğin, cinayet), tüm aşiretlerin yaşlıları geleneksel haklar temelinde "yasa" ya göre kimin haklı olduğuna karar vermek üzere mahkemede toplanıyordu (Kulturologiya, 2008).

Aynı zamanda şamanlar da geleneksel toplumda önemli bir röle sahipti. Şaman sadece inanç faaliyetlerini (ayinleri) yürütmekten başka, aynı zamanda sosyal çatışmaların çözümünde sık sık aracı olarak hareket ediyordu.

Udegey toplumunda aile ve kişilerarası ilişkiler için de birçok arkaik özellikler tipiktir. Buna ilişkin, dilsel tabular da dahil olmak üzere pek çok davranışlar vardı. Örneğin, kadının bir erkeğin kişisel eşyalarına dokunması imkansızdı; ocağa bıçak koymak, ölen kişinin ismini vb. sormak yasaktı. Ekonomi de dahil olmak üzere, insan yaşamının tüm alanları tabulaşmıştı, örneğin bir firtına zamanı düşen ağaçtan asla tekne yapılamazdı.

Udegey toplumunun ataerkillik temeli küçük aile yapısındaydı (Udegeylerin şamanlık öncesi olan ev ocağının kültü Pud ve kadınların yardımcısı Sagdi Ana gibi bazı inançlarında ise anaerkilliğin unsurları gözükmektedir). Ailede ebeveyn hakları, erkek ve kadın 
sorumluluklarının kesın belirlenmesi, o cümleden net bir iş bölgüsü hükmediyordu. Erkek, aileyi gıdasını ve korumasını sağlayıp, temel araçlar ve benzeri konularla ilgilenirken; kadın ev işlerinden sorumlu olarak, çocuk yetiştirmek, yardımcı ve acilen ihtiyaç duyulan iktisadi işlerden (elbise, ayakkabı ve ev eşyalarının yapımı, yabani bitkilerin toplanması ve benzeri) sorumluydu.

Udegey ailesindeki eğitim süreci tamamen erkek çocukların gelecekte aile ekmeği kazananlar olarak gerçek avcılar, balıkçılar olarak hızlı bir şekilde (oyunlarla eğitimi de kapsayarak) öğretilmesine odaklıydı; kız çocuklarıysa doğuştan itibaren, aile ocağının koruyucusu ve neslin devam etmesinin sorumlusu gibi hazırlanıyordu.

Udegey evlilikleri “ekzogoz” - soylar arasıydı. "Yasa” ya (geleneksel yasa) göre, erken yaşlardan itibaren bir kız, farklı bir soydan olan erkek çocuğa eş olarak atanıyordu, karşılık olarak o soydan olan kızlardan biri karşı soydan olan bir erkek çocuğuna atanıyordu. Kızın gelecekteki kocasının ailesine geçme yaşı, ebeveynler arasındaki "anlaşmaya” bağlı olup 3-5 yaştan (bu yaşlarda kız, evlenmeden önce gelecekteki kocasının ebeveynleri için çalışmaya hemen başlard1), 12 (kızlar için normal evlilik yaşı) yaşa kadar değişiyordu (Smolyak, 2000).

\section{AVRUPA KUZEYINDEKİ HALKLAR}

Rusya'nın Avrupa Kuzeyi, batıda Kola Yarımadası ve Karelya'dan doğuda Kuzey Urallara uzanan geniş bir alandır. Kuzeydoğuda ve kuzeyde - ağaçsız bir tundradan oluşsa da bölgenin çoğu tayga ormanları kapsamaktadır. Burası, kendisini Kuzey Kutbu Okyanusu'nun buzlu denizlerinin etkisine bırakan göller ve derin nehirlerle zengin bir arazidir. $\mathrm{Bu}$ nedenle, Dünya'nın diğer kutup bölgeleri gibi, Avrupa Kuzeyi insanlar tarafından nispeten geç dolduruldu. Doğal koşullar önceden bölgedeki düşük nüfusla birlikte, avcılık, balıkçılık ve ormancılığın gelişmesine katkıda bulunmuştur; çiftçilikse önemsiz ve çok sürdürülemez olmuştur.

\section{Avrupa Kuzeyindeki Yerleşim Tarihi}

Avrupa Kuzeyinin toprakları uzun zamandır bir ırklararası karışma alanı olmuştur. Buraya doğudan Moğol kabileleri ve güneyden Europoidler nüfuz ediyordu. Onega Gölü’ndeki Olenyem adasında bulunan eski mezarlık alanlarından birinde, hem Kafkasyalıların hem de Moğolların belirgin kalıntıları bulunmaktadır. Bu yerlerin en eski sakinleri, Beyaz Deniz ve Onega Gölü kıyılarındaki kayalıklarda saklanan çizimlerin (petroglif) de gösterdiği gibi buradaki insanlar avcılık ve balıkçılıkla meşguldu. Arkeolojik buluntular, buradaki ilk insanların yaklaşık 5 bin yıl önce Kola Yarımadası'nda ortaya çıktığını doğrulamaktadır. Avrupa Kuzeyinde ikamet eden ilk kabileler büyük olasılıkla Samodiy grubunun dillerini konuşanlar olmuştur (günümüz Nenslerin diline benziyor). Daha sonra buraya başka etnik gruplar - Fin-Ugor dillerinin temsilcileri nüfuz etti. Kola Yarımadası'nda yaşayan modern Saami'nin nesepleri, başlangıçta Samodiy dilinde konuşmuş olup daha sonra Fin-Ugor dil grubunu benimsemiş oldular (Lobjanidze, Zayats, 2013).

Saamiler (eski adı “Laponlar”), Rusya'nın kuzeyinde olan yerli azınlıkların en batısında yerleşen halktır. Antropolojik türleri, Avrupa ve Moğol türlerinin bir karışımıdır. Saamiler önceden pagan olan bir halktı. Kurban ayinleri için genellikle taştan labirentler ve "seyd" ler (taşlık veya taş yükselmeler) inşa ederlerdi. XV. yüzyılın sonunda. Kola Yarımadası Rus 
devletine geçti, Ruslar buraya Ortodoksluğu (örneğin, Trifon Peçenga) getirdi ve XVI. yüzyılın ortalarında Ortodoksluğu Saamiler de kabul etmiş oldu.

Milattan sonra I. bin yılın sonu - II. bin yılın evvelinde güney-batı Ural bölgesinde, daha sonra soyundan modern Komi-Zıryanlar ve Komi-Permyakların geldiği eski Permyanların büyük kabile birleşimi olmuştur. "Komi” etnonimi için Kama nehrinin adından (Udmurt "Kam” dan) Permiyen “insan” - "kom” kelimesine kadar birkaç etimoloji önerilmiştir (Lobjanidze, Zayats, 2013).

Avrupa Kuzeyinin sakinleri arasında VI. yüzyılda şuanki halefleri Veps olarak adlandırılan bir halk ortaya çıkıyor. Kronolojik, arkeolojik ve dilsel verilere göre Vepsler, (Vologda bölgesinde bulunan) Beyaz Göl'den Onega ve Ladoga göllerine kadar geniş bir alanda yerleşmişlerdi. Bu boşluğa "Mejozerye" (terc. Gölarası) adı verildi. Vepslerin ortaya çıkmasından önce, bu yerler modern Saamilerin ataları tarafından iskan edilmişti. Vepslerin asıl vatanı olarak Güneydoğu Baltık kabul ediliyor. Vepsler oradan milattan sonra ikinci bin yıllığın başlarına taşındı. Bugün, Vepsler Svir nehrinin güneyindeki bölgelerde, yanı sıra güneydoğu Karelya’da ikamet ediyorlar. Dilleri Ural ailesinin Fin-Ugor grubuna aittir.

Artık IX. asırda günümüz Karelaların ataları olan Korela halkı Karelya kıstağında yaşıyordu. Korela halkı, modern güney Karelya ve güneydoğu Finlandiya topraklarında yaşayan yerli kabileler temelinde kuruldu. I. - II. bin y1llıkların ortasında Karelyalıların nesepleri, Ladoga Gölü’nün kuzey ve kuzey-batı kıyısında oturuyorlardı. Korelaların adı Rus eski yazılarında, İskandinav sagalarında, arşivlerde, papa resmi çağrılarında geçiyor. Karelya’lıların Ladoga ve Onega gölleri arasındaki bölgeye göçü, XI. yüzyılda başlamıştır. Onlara bazı Vepsler de karışmış, Karelya'nın kuzeyinde ise Saamilerin bir kısmı da Karelalara katılmıştır. Rus nüfusunun Karela kültürü üzerinde önemli bir etkisi olmuştur. XVI. yüzyılda bu halkın yerleşim bölgesi Rus devletine ait edildi ve Karelalılar Ortodoksluğu kabul etti. Karela dili de Fin-Ugor grubuna aittir. 1617'de Rusya Korelski bölgesini (ismini Korela kalesinden almıştır) İsveç’e terk etmeye zorlandıktan sonra, Karelalar çoğunlukla Yaroslavl ve Tver Volga da dahil olmak üzere Rusya topraklarına taşındı ( Bilgi ve analitik portalı “Naslediye”, 2000).

\section{Avrupa Kuzeyindeki Halkların Maddi Kültürü}

Soğuk iklimlerde Karelalar, Vepsler, Komiler ve Rusların kuzeydeki kırsal konutları, Ruslardan "ödünç” alınan soba içeren yaşam evi ve diğer günlük işler için kullanılan yapıları aynı çatı altında birleştiren bir bloktan ibaretti. Evin süslemesinden oyma işçiliği yaygındı, örtüler, havluları, çatı saçakları oymayla kaplı olmuştur. Pencereler şeritli, testere ve ajur oymacılığı ile tablalarla süsleniyordu. Geometrik nakışlara at ve kuşların oyulmuş figürleri de yerleştirilip oluk kancaları kuşlar şeklinde yapılırdı. Saami ve Nensler hafif sökülebilir konutları (“kuvas”, “veja”, çadırlar gibi) ya da "tupa” isimli küçük kütüklerden oluşan evleri tercih ediyorlardı. Bugün, Saamiler kalıcı ikametgah yerlerinde (Lovozero köyü) standart evlerde yaşıyor, lakin tundrada, ren geyiği otlaklarında genellikle geleneksel konutlarını kullaniyorlar.

Kuzeydeki geleneksel kıyafetler de yerel iklim koşullarına adapte edilmiştir. Çoban Saamiler ren geyiği derilerinden yapılan sıkı elbiseler ve tuvaldan olan uzun gömlekler giyordu. Komi avcıları bugüne kadar kemer kuşağı takılan, dikişsiz kenarları olan deri kaplı yelekler biçiminde av saha kıyafetlerini giyiyor. Bayanların giyimleri daha renkli ve şıktır. Bayan elbisesinin temeli aynı gömleklerten ibaret olmakla beraber eteklerinde, yakalarında ve 
uçlarında nakış işlemeli yanı sıra kollu önlükleri vardı. Veps kadınlarsa genellikle pantolonlar yerine çizgili etekler giyerlerdi. Giysilerdeki parlak renkler, kuzeydeki günlük gri olan hayatı renkli bir şekilde dekore etme girişimidir.

Halkların geleneksel mutfağının merkezinde (Saami ve Nensler hariç), çavdar ve arpa unu ile hazırlanan ürünler var. Balık turtaları (kapalı ve açık), "kalitka”lar (lapa, bezelye veya etli küçük açık köfteler) ve "şanegi”ler (açık turtalar) pişiriliyordu. Hasatın az olduğu yıllarda, una kurutulmuş ağaç kabuğu (genellikle çam) ekleniyordu ve buna göre "Karel kabuğu yedi” deyimi de konuşma diline eklendi. XIX. Yüzyıla kadar ana sebze ürünü şalgamdı, daha sonra lahana, havuç, soğan ve patates çıktı. Et genellikle tatil günlerinde nadiren yeniyordu. Balıklar tuzlanmış, kurutulmuş, süzülmüş ve aynıyla "pelmeni” (terc. mantı) gibi soğukta donduruluyordu (Komi dilinde "pel” kulak anlamına ve "nen” ekmek anlamına gelir). Dondurulmuş pelmenler uzun süre saklana bildiğine ve çabucak hazırlanabilirliğine göre av zamanı alıyordu. Boyunduruk altındaki fiçılara batırılmış mantarlar ("rijık”, "gruzd”, "volnuşka” gibi) ve meyveler (kırmızı yaban mersini, keçiyemişi, yaban mersini) kuzey beslenmesinde önemli bir katkı sağlamıştır.

Şu anda, ulusal politika, Kuzey halklarının geleneksel kültürünün unsurlarını korumayı hedeflemektedir. Farklı folklor koleksiyonları Komi, Veps, Saami dillerinde yayınlanmaktadır, yerli okullarda ulusal diller öğretilerek halk kültürü inceleniyor. Şeltozero köyünde Veps halk kültürünün bir müzesi kuruldu, Veps folklor topluluğu ise Finlandiya, Estonya ve diğer ülke festivallerinin sık sık konuğu oluyor (Kulturologiya, 2008).

\section{KUZEY HALKLARININ "HAYATTA KALMA MÜCADELESİ"}

\section{Genel Durum}

Kuzey halkları 11 milyon kilometrekareye eşit bir alanda yaşıyorlar (bu, Rusya alanının \% 64'ünü teşkil ediyor). Günümüzde bu topraklarda gazın \%90’ından fazlası, petrolün dörtte üçü çıkarılarak, balık ve deniz hayvanı avının yarısı avlanıyor. Odunun \%36'sı buradan ihraç edilmektedir. İş kaynaklarının sadece \%9'u ve sabit varlıkların \%15'ine sahip olan Kuzey, Rusya milli gelirinin beşte birini üretmektedir. Bu nedenle, küçük halkların yaşadığı Kuzey, Sibirya ve Uzak Doğu bölgeleri gerçekten eşsiz bir yakıt ve enerji, mineraller ve hammadde, biyolojik ve diğer kaynaklara sahiptir ( Bilgi ve analitik portalı "Naslediye”, 2000).

Kuzeyde hammadde ve minerallerin keşfi (petrol, gaz, madenler, değerli metaller, vb.) bu bölgenin yaşamının, yerli halkının daha iyiye doğru değişmesi, refah ve ekonomisinin gelişmesi umuduyla karşılandı. Ancak bu gelişmelerle beraber ekonomik alanda, endüstriyel üretimin ulusal-geleneksel üretim türüyle çarpışmasının tartışmalı süreci başladı. Sanayileşme insanlara iş firsatları, hayat verici yeni bir nefes ve sanayıde çalışma izni vereceği gibi görünüyordu. Ancak, her şeyin daha karmaşık olduğu ortaya çıktı. Küçük yerli halkların temsilcileri isteksizce sanayiye giriyor - çünkü sanayı işletmesinde çalışmak sadece uygun niteliklere sahip olmakla beraber ciddi bir psikolojik yeniden yapılandırma da gerektiriyor. (Şu anda, Kuzey yerli halkının sadece \% 6-7'si bu tür işletmelerde istihdam edilmektedir.) Sonuç olarak, yerel dilleri konuşamayan ve yerli halkların ulusal kültürünün gelişimine ilgisiz olan işçiler buraya getirilmektedir. Aynı zamanda, birçok insan yerli halkın kendilerine bile 
ilgisizdir. Bu büyük bir endişe kaynağı ve yerli halkın bir kısmı tarafından kendi ulusal egemenliklerinin ihlali olarak algılanmaktadır ( Bilgi ve analitik portalı "Naslediye", 2000).

Kuzeydeki küçük halkların gelişimi için, geleneksel ekonomi türlerinin korunması büyük önem taşımaktadır. Ortaya çıkan pazar ilişkileri yükselişi bu bakımdan önemli bir rol oynayabilir. Bu arada, Uzak Kuzey’de bu ilişkiler neredeyse hiç yok gibi. Burada toptancı bir emtia sistemi mevcut, piyasa durumunu inceleyecek yapılar yok, üretilen ürünlerin ezici çoğunluğu devlete gidiyor, yerli nüfusun (avcılar, ren geyiği yetiştiricileri, balıkçıların vb.) dış dünyayla doğrudan ilişsisini temin edecek etkili bir mekanizma da mevcut değil.

Bilindiği gibi Rusya, öncelikle Kuzey halkları sayesinde, dünya kürk üretiminde öncü bir konuma sahiptir ve aynı zamanda uluslararası pazarda bazı kürklerin tek veya ana tedarikçisi konumundadır. Kutup tilkisi, tilki, gümüşü vizon (kafes vizonu) her zaman çok değerli olmuştur. Kürk ülkeye önemli miktarda dövizin akışına sebep olurken yerel avcılardan çok düşük fiyatlarla alınmaktadır.

Geçmişte, Çukçi, Koraklar, Nensler, Saamiler ve diğer kuzey halkların ekonomisinin önemli bir kolunu avcılık teşkil ederdi, şimdiyse bu alana kısıtlamalar koyulmuş durumda. Kuzey’in birçok halkı ren geyiği yetiştiriciliği ile uğraşmaktadır. Doğal olarak, günümüzde, ren geyiği sürüleri, daha önce oynadığı gıda ihtiyaçlarını karşılamada artık olağanüstü bir rol oynamıyor. Fakat bu rolün küçümsenmesi de, Uzak Kuzey’deki küçük halkların geçim kaynaklarını zorlaştırdı.

\section{Çevre ve İnsan Sorunları}

Kuzey'in endüstriyel gelişimi, ren geyiği yetiştiriciliğini ve avcılığı olumsuz yönde etkiledi. Geyiklerin başlıca gıdaları ren geyiği yosunu arazileri binlerce sondajın etrafında büyük yakılmış sahalara dönüşmüştür. Tayga üzerinden gaz ve petrol boru hatlarıyla geçilerek, demiryolları ile kesildi. Bir dizi yeni şehir ve çok sayıda işçi yerleşimi ortaya çıktı. Hızlandırılmış ağaç kesimi devam etti.

Yakın zamana kadar, yoğun endüstriyel gelişmeyle bağlı olarak, küçük halkların gerçek anlamda ana yerlerinden sürülme prosedürleri uyguland1. Örneğin Oroçilerin, 1956'dan beri beş kez ikamet yeri değiştirildi. Sonuç olarak günümüzde bu halkı temsil eden sadece 631 kişi kaldı. Evenk, Nanay, Ulçi, Ugedey, Eskimo, İtelmen, Orok, Oroçi, Yukagir'lerin \%10 ile \%35 kadar oranı şimdi sık yerleşim coğrafyasının dışında yaşıyor ( Bilgi ve analitik portalı "Naslediye", 2000).

Kuzey’in endüstriyel kalkınmasına, halkların yaşam alanlarının tahrip edilmesi, yapay birleştirme, yaşam biçimi ve koşullarının standardizasyonu eşlik etti. Arktik Okyanusu'nun nehirleri ve kıyı sularındaki zararlı maddelerin oranı izin verilen maksimum sınırların 5-6 kat fazlasına ulaşmış durumda. Birçok yerde içme suyuyla ilgili zorluklar ortaya çıktı. Büyük çapta toprak kirliliği de meydana geldi. Öyleki, çevrebilimciler Hantı-Mansiysk topraklarının her metrekaresine 20'den 50 kiloya kadar petrolün döküldügünü hesapladılar. Sadece Tümen bölgesinin kuzeyinde, petrol üretimi 28 doğal kaynaklı nehrin ve 11 milyon hektar ren geyiği otlak sahasının tahrip olmasına yol açtı.

Erozyon ve termokarst süreçleri tehlikeli seviyeye ulaştı. Birçok çevre ekonomisti, Kuzey'in bazı bölgelerinin ek yüke dayanamayacağına inanıyor. Kuzey bölgelerinde yaşayan halkların yaşam alanı bozulmuş halde. Bu toprakların küçük halkları onların geçim vesilesi olan doğaya neredeyse tamamen bağımlıdır. 
Çevresel ve sosyal durumun değerlendirilmesinde sadece devlet departmanların değil, aynı zamanda sıradan göçmen işçilerin doğa ile olan ilişkileri büyük öneme sahiptir. Bölgedeki yerli nüfusun kamuoyuna göre, hiç de sebepsiz yere olmadan, Kuzey'in yerli halkıyla göçmenler arasında doğaya yönelik tutumlarda temel bir farklılığın olması fikri ortaya çıkmıştır. Yerli insanlar için doğa onların yaşam alanıdır, yerliler kendilerini doğadan koparmadan, değerlerini rasyonel bir şekilde kullanıyorlar. Aynı zamanda, bölgede geçici olarak ikamet eden göçmenler doğayı, kendisinden daha çok kar elde ederek kendisine daha az maliyet sarf edilen bir ortak kısmında görüyor. Geçici işçiler doğal çevreyi sakatlayarak sadece maddi hasarlara neden olmuyor, aynı zamanda yerli halkların öfkesine ve çoğu zaman hatta düşmanlığına da sebep oluyor.

\section{Sosyo-Demografik Sorunlar}

Yerli halklar ekonomik koşullar ve düşük yaşam standardından dolayı acı çekmeye devam ediyor. Kuzey halklarının aşırı sert yaşam koşullarında, sosyal sorunlar özel bir rol oynamaktadır. Bunun için daha önce ve şimdi fonlar tahsis edilse bile bu fonların etkisi düşük kalıyor. Küçük halkların yaşadığı toprak ve bölgelerin sosyo-ekonomik gelişimi için ayrılan kaynaklardan yalnızca \%10-15'i muhataplarına ulaşmıştır. Böylece son yıllarda orada sosyal alanda gözle görülür bir gelişmenin olmaması tesadüf değildir. Ulusal yerleşim yerlerinin düzenlenmesi ve tüketici hizmetleri düşük seviyede olup, pazar ilişkilerine geçiş süreci nedeniyle durum daha da karmaşık hale gelmiştir.

Kuzeyde, kişi başına ortalama 1.5 ile 7 metrekare konut arazisi ayrılmış olmakla beraber genellikle bu konutlar eski püskü, fakir binalardan ibarettir. Çukotka, Taymır, Evenkiya ve diğer yerlerde insanlar donmamak için bir odaya birkaç aile şeklinde sığınıyor. Her ikinci veya üçüncü ailenin daha iyi yaşam koşullarına ihtiyaç duymakta. Yamalo-Nenets Bölgesi'ndeki birçok ren geyiği çobanının yalnızca evi değil, kendi çadırları bile yok. Ulusal köylerin çoğunda anaokulları, tıbbi tesisler normal koşullara sahip olmayan, çalışmaya müsait olmayan alanlara, genellikle kritik durumda olan mekanlara yerleştirilir.

"Uygarlığın", bilimsel ve teknolojik gelişimin olumsuz etkisiyle bağımlı olarak yerli kuzeylilerin zihinsel sağlığında keskin bozulmalar müşahede ediliyor (sarhoşluk, alkolizm, suç işleme, saldırganlık gibi). Doğal olmayan ölümler, ölüm sayısının büyük bir yüzdesini oluşturur. 80’lerde, Kuzey’deki yerli halktan her ikinci ölünün ölme sebebi günlük hayat zamanı alınan travma, cinayet ve intihar olmuştur ki, bu gösterici tüm ülke istastistik ortalamasından 3-4 kat daha yüksektir. Kuzeydeki küçük halk temsilcilerinin ortalama ömrü yalnızca 42-46 yaş arasıdır ve bu gösterici Rusya genelinde olan durumdan çok daha düşük (Prina, 2014).

\section{0. İSTATISSTIKSEL VERILLER}

Doğal olarak, günümüzde bazı küçük halklar nüfus artışı ile karakterize edilirken diğerlerinde azalmalar mevcut. Böylece, KYH sayısı ve değişiminin dinamikleri hakkındaki veriler iki gruptan oluşan bir tabloda özetlenebilir: 
Tablo1: KYH Sayısı ve Değişiminin Dinamikleri Hakkındaki Verileri (Russian Association of Indigenous Peoples of the North - RAIPON, 2011)

\begin{tabular}{|l|l|}
\hline $\begin{array}{l}\text { Sayısı yükselen halklar ve onların } 2010 \text { yılına } \\
\text { göre olan sayıları: }\end{array}$ & $\begin{array}{l}\text { Sayısı azalan halklar ve onların 2010 yılına göre } \\
\text { olan sayıları: }\end{array}$ \\
\hline Evenler (22000) & Nanaylar (16000) \\
\hline Evenkler (37100) & Ulçiler (2800) \\
\hline Hantılar (31000) & Udegeyler (1500) \\
\hline Mansiler (12000) & Negidaller (600) \\
\hline Nensler (45000) & Vepsler (6000) \\
\hline Nganasanlar (700) & Selkuplar (3650) \\
\hline Ensiler (270) & Şorslar (12900) \\
\hline Çukçiler (16000) & Rusya Eskimoları (1730) \\
\hline & Ketler (1220) \\
\hline & Kerekler (4) \\
\hline &
\end{tabular}

\section{SONUÇ}

Şimdiye kadar, ne yazık ki, Rusya Devlet Başkanı ve Hükümeti, bu halkların sorunlarının kökten çözümüne yönelik ne tür bir politika uygulayacağına dair karar almamıştır. Uyguladığı politikaların temeli, devlet kurumlarının epizodik hayır faaliyetlerine (mali, maddi yardım sağlama, devlet ve kooperatif ticaretinin düzenlenmesi vb. gibi bir dizi önlemin uygulanması) indirgenmesinden ibarettir. Açıkçası bu, kuzeyli halkların sosyo-ekonomik, çevresel, demografik sorunlarını çözmek için yeterli değildir. Bir diğer gerçeği not etmek gerekirse, bu veya diğer önlemler, genel olarak, yukarıdan, yani Kuzey halklarının geniş kesimleri onların gelişiminde yer almamaktadır ve görüşleri sıklıkla dikkate alınmamaktadır. Politika öncelikle halkın çıkarlarına ve ihtiyaçlarına dayanmalıdır.

Geleneksel tarım türlerini korumak için toprak sahalarının genişletilmesi, doğal yaşam alanlarının iyileştirilmesi, yaşam beklentisini ve nüfus büyüklüğünü artırmaya yönelik tedbirler, küçük halkların normal yaşamları için gerekli koşulları yaratma yönünde politikalar gerçekleştirilmeli.

Çevre sorunlarının büyük aciliyeti dikkate alındığında, bu bölgedeki doğanın korunması için uzun vadeli bir devlet programı benimsemek ve sistematik olarak uygulamak, ülkenin kuzeyinde çevre yönetimi için özel bir rejim oluşturacak önlemler almak gerekli olacaktır. Rusya Federasyonu hükümeti, endüstriyel kalkınmaya tabi olmayan ulusal, etnik bölgeler veya öncelikli çevre yönetimi bölgelerinin oluşturulması hakkında uygun bir belge geliştirmelidir.

Doğanın haksız yere imhasına, kaçak avcılığa karşı yönelik daha sert yaptırımlar olmalıdır. Yasalar, Kuzey halklarının, doğal ortamlarının ve tarihsel yaşam alanlarının tahrip edilmesinin telafisi yönünde reel politikalar uygulamalı ve Kuzey halklarına bu tahribatlardan ötürü tazminat elde etme hakkı tanımalıdır.

Küçük Yerli Halkların sağlık durumu dikkate alındığında, sağlık hizmetleri için ayrılan fonların, hastane ağı ve klinikler inşaatı ve maddi desteklerin artırılması gerekmektedir. Kuzey'deki sağlık kurumlarının yeterli düzeyde personel bulunmadığını göz önünde bulundurarak, eğitimlerine ve özellikle de yerel halklardan bu alanlar için kadroların seçilmesine dikkat edilmeli. Mobil tıbbi birimlerin çalışması sağlanmalı. Özellikle göçebe ya 
da yarı göçebe bir yaşam tarzı sunan nüfus için, terapik ve profilaktik bakımın önemli ölçüde iyileştirilmesi gerekmektedir.

Eğitim koşıllarının ve düzeyinin iyileştirilmesine yönelik tutarlı adımlar atılmalı. Neredeyse tamamen okul müfredatlarından dışlanmış olan Kuzey halklarının anadillerine yönelik tutum değiştirilmelidir. Radyo ve televizyon yayıncılığını Kuzey halklarının dillerinde genişletilmesi gerekiyor. Bu dillerde yayınlamak için özel kitap yayıncılarına da ihtiyaç vardır. Kuzey Halkları Enstitüsü’nün veya bu tür bir üniversitenin kurulmasının hayati bir önemi vardır.

Kısacası, kuzeydeki küçük halkların yeniden canlanması ile ilgili sorunlar hacimli ve karmaşıktır. Dünyanın her yerinde küçük ulusal azınlıkların refahı, yaşam standardı ve kültürünün korunması (örn, Amerika'daki Hintliler, Avustralya Aborjinleri, Japonya Aynleri, vb.) ülkenin "kartviziti” haline gelmiştir. Bu nedenle, Kuzey’in küçük halklarının Rusya için kaderlerinin önemi, ülke nüfusunun yalnızca \%0,1'ini oluşturan küçük sayılarından orantısız şekilde daha büyüktür.

\section{KAYNAKLAR}

Bilgi ve analitik portalı "Naslediye". (2000, Ağustos 1). Borba Za Vijivaniye Narodov Severa. Nisan 2019 tarihinde Naslediye.ru: http://old.nasledie.ru/politvnt/19_12/article.php?art=8 adresinden alınd

Bgograz, V. (1934). Luoravetlanskiy (Chukotskiy) Yazık. Y. ALKORA içinde, Yazıki i Pismennosti Narodov Severa. (s. 5-46). Moskova-Leningrad: Gos. Ush.-Ped. İz.

Kormushin, İ. (1998). https://bigenc.ru. Nisan 2019 tarihinde Bolshaya Rossiyskya Ensiklopediya: https://bigenc.ru/linguistics/text/4216024 adresinden alınd1

Kulturologiya. (2008, Mayıs 12). Evenki: Pochemu “Aristokratı Sibiri”' Migrirovali v Kitay. Nisan 2019 tarihinde Kulturologia.Ru: https://kulturologia.ru/blogs/180118/37506/ adresinden alınd1

Lobjanidze, A.; Zayats, D. (2013). Etnokulturnıye Regionı Mira. Uchebnoe Posobiye. Moskva: Prometey.

Obsheobrazovatelnıy Jurnal "Sezonı Goda". (2011). https://сезоны-года.pф. Nisan 2019 tarihinde Sezon1 Goda: https://сезоны-года.рф/народ\%20Чукчи.html. adresinden alındı

Polyanin, A. (2012). Narodı Severa. İstoria i Sovremennost. Nisan 2019 tarihinde https://www.edu.severodvinsk.ru:https://www.edu.severodvinsk.ru/after_school/nit/2012/polyanin/eve ns.html adresinden alınd 1

Prina, F. (2014). Zashita Prav Menshinstv i Korennıkh Narodov Rossiyskoy Federasii. Budapeşte: Minority Rights Group Europe (MRG). 
Prokopyeva, P., Shadrin V., Prokopyeva A. (2012, Mart 27). Korkodonskiye Ukagirı V Nachale XXI. Veka. Severo-Vostochniy Gumanitarnıy Vestnik(2), 41.

Russian Association of Indigenous Peoples of the North - RAIPON. (2011, Aralık 18). Danniye Vserossiyskoy Perepisi 2010. Nisan 2019 tarihinde http://www.raipon.info: http://www.raipon.info/peoples/data-census-2010/data-census-2010.php adresinden alındı

Russian Association of Indigenous Peoples of the North - RAIPON. (2003). Evenki. Nisan 2019 tarihinde http://www.raipon.info: http://www.raipon.info/peoples/evenks/evenks.php adresinden alınd1.

Russian Association of Indigenous Peoples of the North - RAIPON. (2003). Chukchi. Nisan 2019 tarihinde http://www.raipon.info:http://www.raipon.info/peoples/chukchi/chukchi.php adresinden alınd1.

Smolyak, A. (2000). www.etnosy.ru. Nisan 2019 tarihinde Etnosyklopedia: http://www.etnosy.ru/node/349 adresinden alınd1.

UN Human Rights Council - UNHRC. (2007). 'Report by the Special Rapporteur on contemporary forms of racism, racial discrimination, xenophobia and related intolerance’. Doudou Diène.

UN Human Rights Council - UNHRC. (2010). 'Report of the Special Rapporteur on the situation of human rights and fundamental freedoms of indigenous peoples', Situation in the Russian Federation. James Anaya.

UNESCO. (2014, Mayıs 15). UNESCO Atlas of the World's Languages in Danger. Nisan 2019 tarihinde http://www.unesco.org: http://www.unesco.org/languages-atlas/index.php adresinden alınd. 